\title{
Laboratory Studies on Phosphorus Removal from Nigeria's Agbaja Iron Ore by Bacillus Subtilis
}

\author{
C. N. Anyakwo ${ }^{1}$ and O.W. Obot $^{2}$ \\ ${ }^{1}$ Department of Metallurgical and Materials Engineering, Federal University of Technology, \\ Owerri, Nigeria. Email: charlesanyakwo@yahoo.com \\ ${ }^{2}$ Department of Mechanical Engineering, Faculty of Engineering, University of Uyo, Nigeria. \\ Email: obotowo2009@gmail.com
}

\begin{abstract}
The investigation into whether or not Bacillus subtilis can remove phosphorus from the Nigerian Agbaja iron ore was carried out with careful monitoring of the population of the removing agent as well as $\mathrm{pH}$ of the system. $1.00 \mathrm{~mm} / 0.50 \mathrm{~mm}, 0.50 \mathrm{~mm} / 0.25 \mathrm{~mm}$, and $0.25 \mathrm{~mm} / 0.125 \mathrm{~mm}$ ore fractions obtained from sieving of the crushed iron ore in Shital Test kits, were used in sub-merged culture of nutrient broth (NB) medium for 10 weeks. B. subtilis which was part of the rich microflora found on the ore surface was cultivated in nutrient-rich media and later inoculated in sterilized $100 \mathrm{ml}$ of NB in $250 \mathrm{ml}$ conical flask and $1 \mathrm{~g}$ of each of the equally sterilized ore fractions was added. At weekly intervals, a set of samples was removed, treated through series of chemical reactions to obtain ammonium phosphomolybdate precipitate which was back-titrated with $0.1 \mathrm{~N}-\mathrm{HCl}$ to determine the amount of phosphorus left in samples and consequently, the amount removed. The laboratory investigations found out that $B$. subtilis has the capability to remove phosphorus from the Nigerian Agbaja iron ore, recording an impressive average of $65.73 \%$ P. Also found out was the systematic reduction in bacterial cells count in colony forming unit per mililitre, the initial load $3.4 \times 10^{5} \mathrm{cfu} / \mathrm{ml}$ increased to $4.8 \times 10^{7} \mathrm{cfu} / \mathrm{ml}$ from where it declined to $1.3 \times 10^{6}$ $c f u / m l$, which justified the $\mathrm{pH}$ trend observed during the process of cumulative phosphorus removal. The reduction in microbial activity may be attributed to antimicrobial components of the ore, pyrite, and other heavy metals which may have affected the phosphorus uptake from ore.
\end{abstract}

\section{INTRODUCTION}

In 2007 the world iron ore production rose by $11 \%$ to 1.640 billion tons. It was expected that in 2008 and 2009 the trend was likely to continue. According to the latest report released by 
the United Nations Conference on Trade and Development (Unctad), it was found out that world production of iron ore fell by $6.2 \%$ in 2009 to 1.52 billion tons [1].

Iron ore is one of the solid minerals found in the Federal Republic of Nigeria. 20 iron ore deposits have been documented [2]. The Nigerian Agbaja iron ore is the largest of all the deposits and estimated to be about 1.2 billion tons [3]. The principal constituent mineral is goethite with minor hematite, maghematite, siderite, quartz, kaolinite and pyrite [2]. A recent analysis of Agbaja iron ore using AAS (UniCam 939), calorimetry and titrimetry methods is presented in Table 1.

Table 1 The Nigerian Agbaja Iron Ore Analysis

\begin{tabular}{|l|l|l|l|l|l|l|l|l|l|l|}
\hline Sample & $\begin{array}{l}\mathrm{Fe} \\
\%\end{array}$ & $\begin{array}{l}\mathrm{SiO}_{2} \\
\%\end{array}$ & $\begin{array}{l}\mathrm{P}_{2} \mathrm{O}_{5} \\
\%\end{array}$ & $\begin{array}{l}\mathrm{MgO} \\
\%\end{array}$ & $\begin{array}{l}\mathrm{Cu}_{2} \mathrm{O} \\
\%\end{array}$ & $\begin{array}{l}\mathrm{ZnO} \\
\%\end{array}$ & $\begin{array}{l}\mathrm{LOI} \\
\%\end{array}$ & $\begin{array}{l}\mathrm{S} \\
\%\end{array}$ & $\begin{array}{l}\mathrm{MnO}_{2} \\
\%\end{array}$ & $\begin{array}{l}\mathrm{Al}_{2} \mathrm{O}_{3} \\
\%\end{array}$ \\
\hline $\begin{array}{l}\text { Ore } \\
\text { sample }\end{array}$ & 51.50 & 0.57 & 1.25 & 0.08 & 0.005 & 0.091 & 8.01 & 3.25 & 0.001 & 34.77 \\
\hline
\end{tabular}

Agbaja iron ore which analyzed $43-51.50 \% \mathrm{Fe}$ is very rich in phosphorus $\left(1.5-3.0 \% \mathrm{P}_{2} \mathrm{O}_{5}\right)$ and the phosphorus is uniformly associated with the iron minerals [4, 5, 6, 7]. Phosphorus is a deleterious inclusion that is responsible for steel brittleness causing it to fracture and snap at very low stress values, also associated with phosphorus are the problems of strong primary segregation during solidification of castings and the formation of high phosphorus brittle streaks between metal grains thereby impeding plastic deformation. Thus, for high quality steels, the phosphorus acceptable level is in the range $0.03-0.02 \mathrm{Wt} \%$ or even less [8].

Apart from the high phosphorus status, the Agbaja iron ore is also associated with beneficiation difficulties $[9,10,11]$ which, after many attempts by researchers, resulted in its abandonment on grounds of above technical reasons. In mineral processing the use of microbes has gained significant popularity and the works of researchers in this area are well documented. This evolving trend popularly called "biobeneficiation" and which has been defined as - a biological process in which the microorganisms used produce as a consequence of their metabolism, a chemical by-product (mineral acids, organic acids, polymers, enzymes, chelating agents, etc) is fast gaining a wider applicability [sic]. The by-product in turn attack the gangue minerals contained in the ore, dissolving them and thus producing their selective removal [12]. Using the bacterium Burkholderia caribensis isolated from a Brazilian highphosphorus iron ore [13], a team of researchers were able to mobilize between $5-20 \%$ of the phosphorus originally contained in the ore in 21 days of treatment in shake-flask cultures. Similarly in another work, Aspergillus niger also isolated from the same Brazilian highphosphorus ore was employed to remove phosphorus from the same ore and again in 21 days between 13.8-33.2\% was achieved [14]. In the beneficiation of iron ore slime Aspergillus niger and Bacillus circulans were able to remove alumina with B. circulans and A. niger showing 39 and 38 percents, respectively of alumina removal after 6 and 15 days, respectively of in situ leaching at $10 \%$ pulp density. Also a culture filtrate leaching with $A$. niger removed $20 \%$ alumina at $2 \%$ pulp density with 13 day old culture filtrate. $B$. circulans was more efficient than $A$. niger for selective removal of alumina [15]. Earlier on A. niger 
isolated from Nigeria's Agbaja iron ore was used to mobilize phosphorus from the same ore and in 49 days of leaching, 81\%, 63\% and 68\% efficiencies for Mesh 5, Mesh 100 and Mesh 250 grain sizes, respectively, were achieved [16]. The objective of the present study therefore, is aimed at using $B$. subtilis, a bacterium, to biobeneficiate the Nigerian Agbaja iron ore to a metallurgical acceptable level. Biobeneficiation is an alternative, ecologically friendlier approach, to the traditional physical and chemical methods of dephosphorisation.

\section{MATERIALS AND METHODS}

The iron ore, Plate 2.1, was collected from Agbaja, an indigenous community near Lokoja, Kogi State of Nigeria. Standard glass wares, heavy equipment, chemicals and disposables used in the phosphorus removal process were sourced locally.

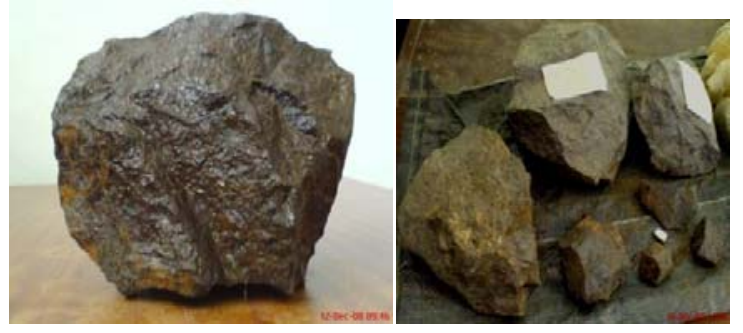

Plate 2.1 Agbaja iron ore

$1 \mathrm{~kg}$ of the iron ore was manually crushed in the laboratory using hammer and anvil to generate tiny particles which were screened using Shital Test sieves into $1.00 / 0.50 \mathrm{~mm}$, 0.50/0.25mm and 0.25/0.125mm particle size fractions, Plates 2.2.

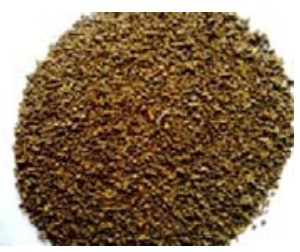

(a)

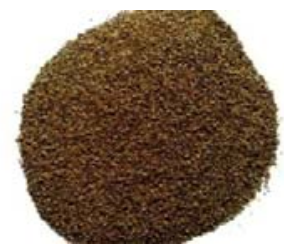

(b)

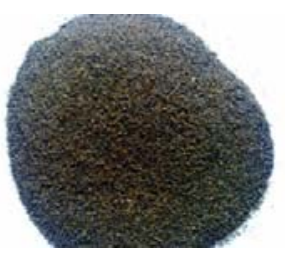

(c)

Plate 2.2 Ore Sample Particle Size Fractions

(a) $1.00 / 0.50 \mathrm{~mm}$, (b) $0.50 / 0.25 \mathrm{~mm}$, (c) $0.25 / 0.125 \mathrm{~mm}$

$10 \mathrm{~g}$ of each of the iron ore particle size fractions was weighed using Adventurer-AR3130 (with readability $001 \mathrm{~g}$ ) and placed in $90 \mathrm{ml}$ of sterile water in $250 \mathrm{ml}$ conical flask and then serially diluted to $10^{-6}$. Using a pipette $1 \mathrm{ml}$ from each final dilution was taken to seed 10 sterile Petri dishes and about $20 \mathrm{ml}$ of mineral oil medium, the recipe of which is given in Table 2.1., at $45{ }^{\mathrm{O}} \mathrm{C}$ was added to each seeded Petri dish, swirled and allowed to stand for 14 days. 
Two batches of 5 Petri dishes each were allowed to stand aerobically and anaerobically. At the end of this duration, growth colony of microbes was observed.

\begin{tabular}{|c|c|c|}
\hline \multirow[t]{2}{*}{ Table 2} & \multicolumn{2}{|c|}{ Recipe for Mineral Oil Medium } \\
\hline & Reagent & Quantity, \\
\hline & Sodium Chloride & 1.20 \\
\hline & Iron Sulphate & 1.02 \\
\hline & Magnesium Sulphate & 0.05 \\
\hline & $\begin{array}{l}\text { Potassium di-hydrogen } \\
\text { Phosphate }\end{array}$ & 0.25 \\
\hline & $\begin{array}{l}\text { Di-potassium } \\
\text { hydrogen Phosphate }\end{array}$ & 1.25 \\
\hline & Agar-agar & 6.00 \\
\hline & Water & 1 litre \\
\hline
\end{tabular}

Bacterial colonies were sub-cultured in nutrient agar and incubated for 24 hours $28 \pm 2{ }^{\circ} \mathrm{C}$. Using the standard manual for bacterial identification [17], the developed growth colonies were characterized and identified as Bacillus subtilis. These microbes were preserved for subsequent use in the experiment.

19.85g of NB powder was mixed with 2.4 litres of distilled water in a sizeable container to produce NB medium. $100 \mathrm{ml}$ of this was dispensed into $250 \mathrm{ml}$ conical flasks. The conical flasks with content were sterilized using autoclave at $121{ }^{\circ} \mathrm{C}$ at 15 psi for 15 minutes. On cooling, $1 \mathrm{~g}$ of the already sterilized set of samples was accurately weighed and mixed with each of the $100 \mathrm{ml}$ NB medium earlier dispensed into the $250 \mathrm{ml}$ flasks. 33 flasks were prepared. $1 \mathrm{ml}$ of the $B$. subtilis broth culture was used to inoculate each of the flasks aseptically. 3 conical flasks were not inoculated with the test organisms, and they served as the control.

Finally, a batch of 3 conical flasks representing each of the 3 particle size fractions was removed for phosphorus analysis weekly. The $\mathrm{pH}$ and cells count of the microbes were noted on weekly basis as well. The samples were treated through series of standard chemical reactions [18] to obtain ammonium phospho-molybdate precipitate which was back-titrated with $0.1 \mathrm{~N}-\mathrm{HCl}$ to determine the amount of phosphorus left in samples and consequently, the amount removed. The data obtained from above procedure were organized and presented in Figures 1-5. 


\section{RESULTS AND DISCUSSION}

The result of phosphorus removal by $B$. subtilis in nutrient broth medium using the ore particle size fractions $1.00 / 0.50 \mathrm{~mm}, 0.50 / 0.25 \mathrm{~mm}$ and $0.25 / 0.125 \mathrm{~mm}$ for 10 weeks is presented in Figure 1. From the initial ore concentration of $0.89 \mathrm{wt}$ \% the phosphorus content was lowered to 0.368 wt. \%, $0.258 \mathrm{Wt}$. \% and 0.289 wt. \%, respectively for the particle size fractions by Week 10 . The microbes removed phosphorus rapidly from Week 1 to Week 7 and afterwards phosphorus removal was observed to have stagnated from Week 8 to Week 10.

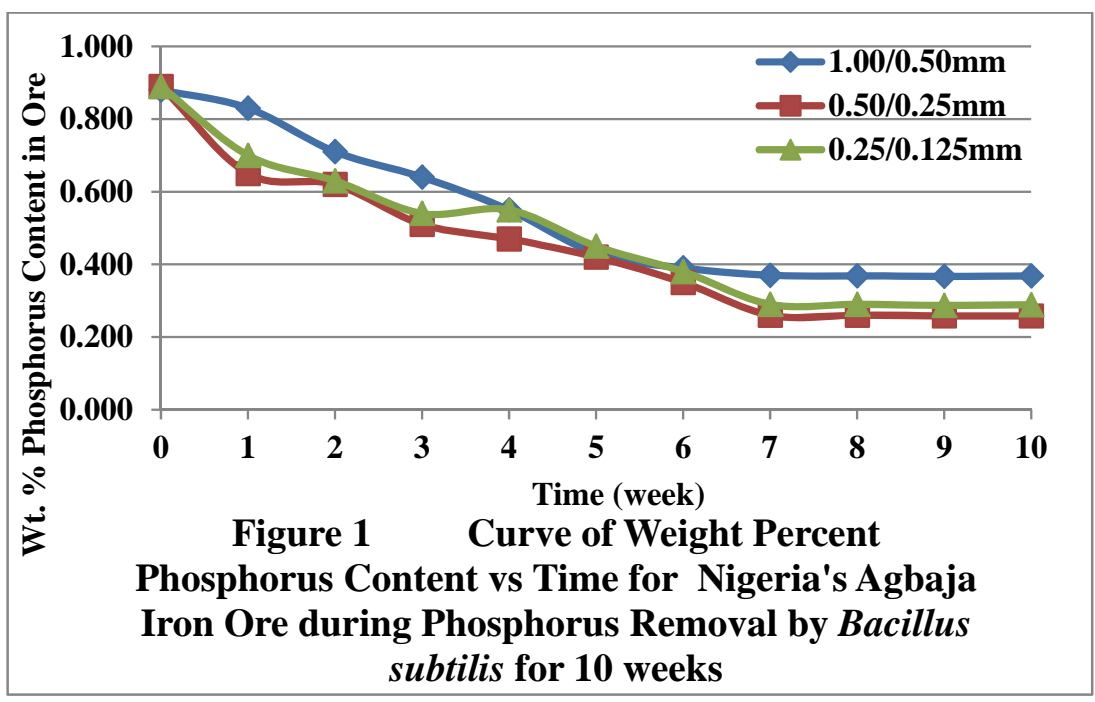

The variation of the $\mathrm{pH}$ of the medium with time during the experimentation period is shown in Figure 2. The pH increased from the initial 6.91 to 8.19 by Week 2 and thereafter remained in the basic region till Week 10. It therefore remained in the basic region for most of the experimental period.

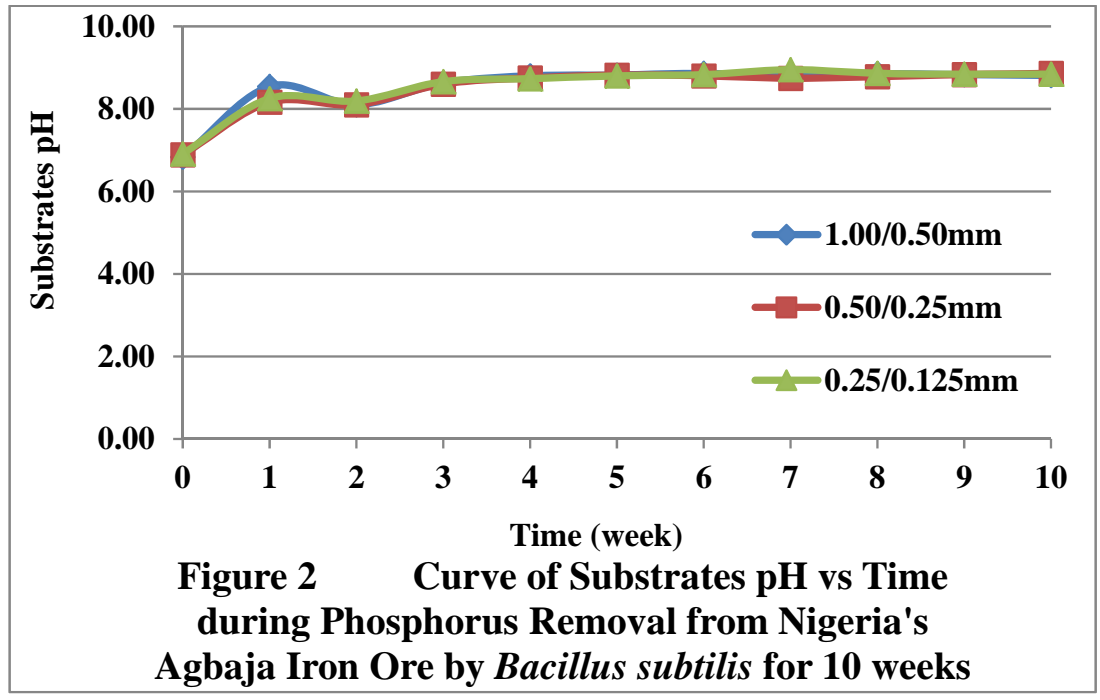


The log of the growth of $B$. subtilis in the nutrient broth medium bearing the iron ore during phosphorus removal for 10 weeks is presented in Figure 3.

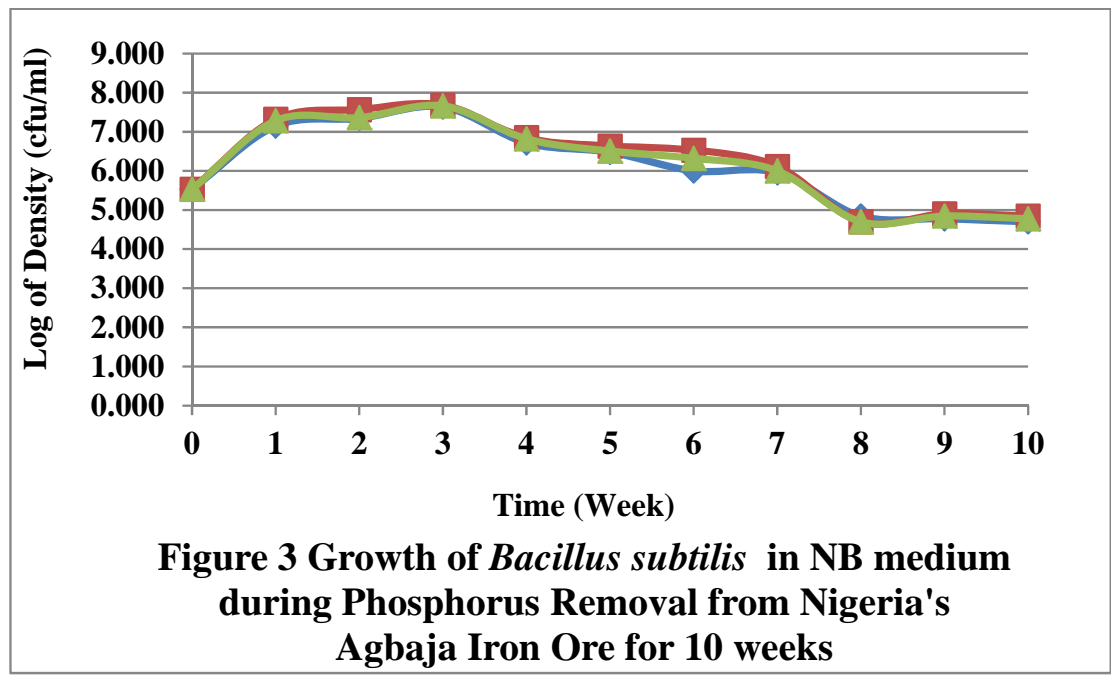

Figures 4(a) and (b) present the variation of the iron ore phosphorus content, the substrates $\mathrm{pH}$ and the $\log$ of density during phosphorus removal from Agbaja ore $1.00 / 0.50 \mathrm{~mm}$ and $0.50 / 0.25 \mathrm{~mm}$, respectively for 10 weeks by $B$. subtilis. It is observed that a rapid phosphorus removal occurred in Week 1 lowering its content from an initial 0.89 wt. \% to 0.65 wt. \%. The same period experienced a rapid cells multiplication from the initial log of cells density $5.531 \mathrm{cfu} / \mathrm{ml}$ to $7.322 \mathrm{cfu} / \mathrm{ml}$ also, an increased $\mathrm{pH}$ from 6.89 to 8.16 . A steady phosphorus removal starting from Week 2 till the end of Week 7 was observed and thereafter it stagnated till the end of the experiment in Week 10. This period of an intensive phosphorus removal was also coincident with the time of maximum cells growth.

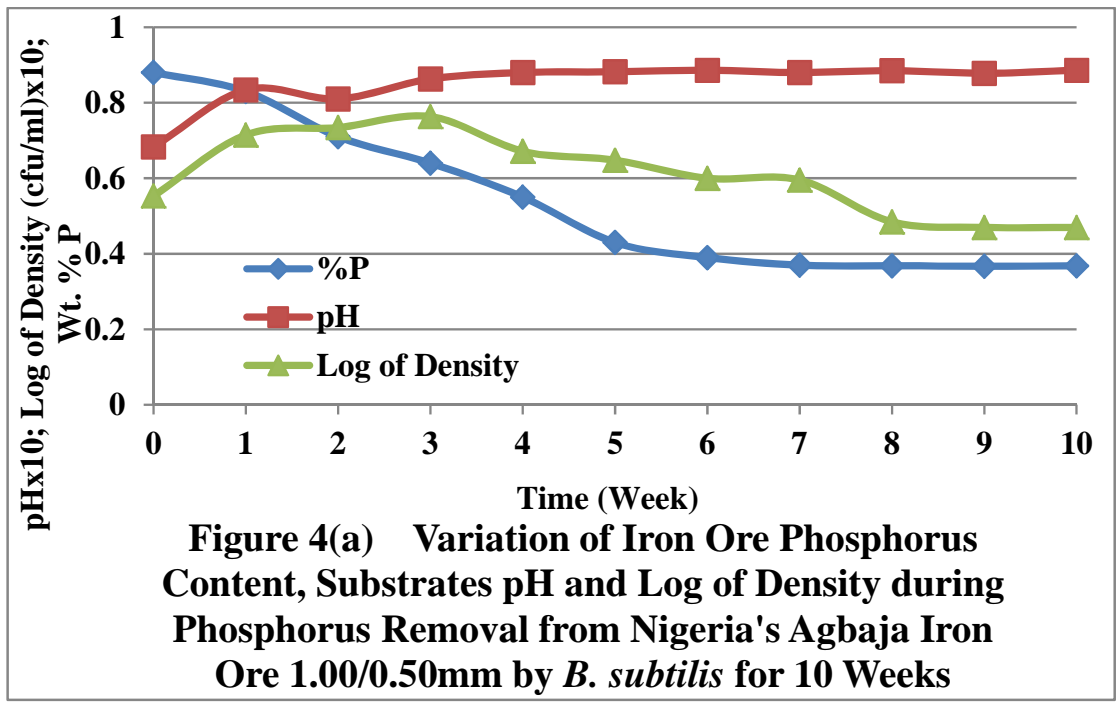




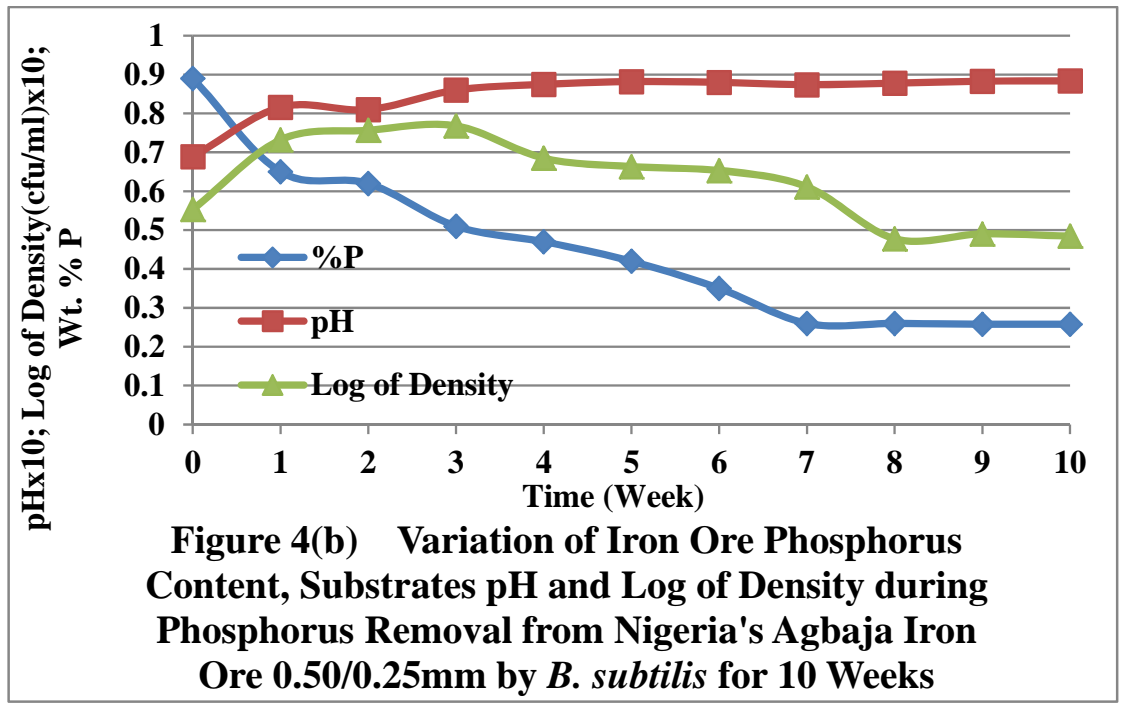

Figure 5 presents the percent phosphorus removed by $B$. subtilis in 10 weeks. The percent phosphorus removed from the ore was calculated using Equation 1.

$$
\% P=\frac{\% P_{\text {initial }}-\% P_{\text {final }}}{\% P_{\text {initial }}} \times 100
$$

$\% P_{\text {initial }}$ - the initial weight $\%$ phosphorus content in ore

$\% P_{\text {final }}$ - the final weight $\%$ phosphorus in treated ore.

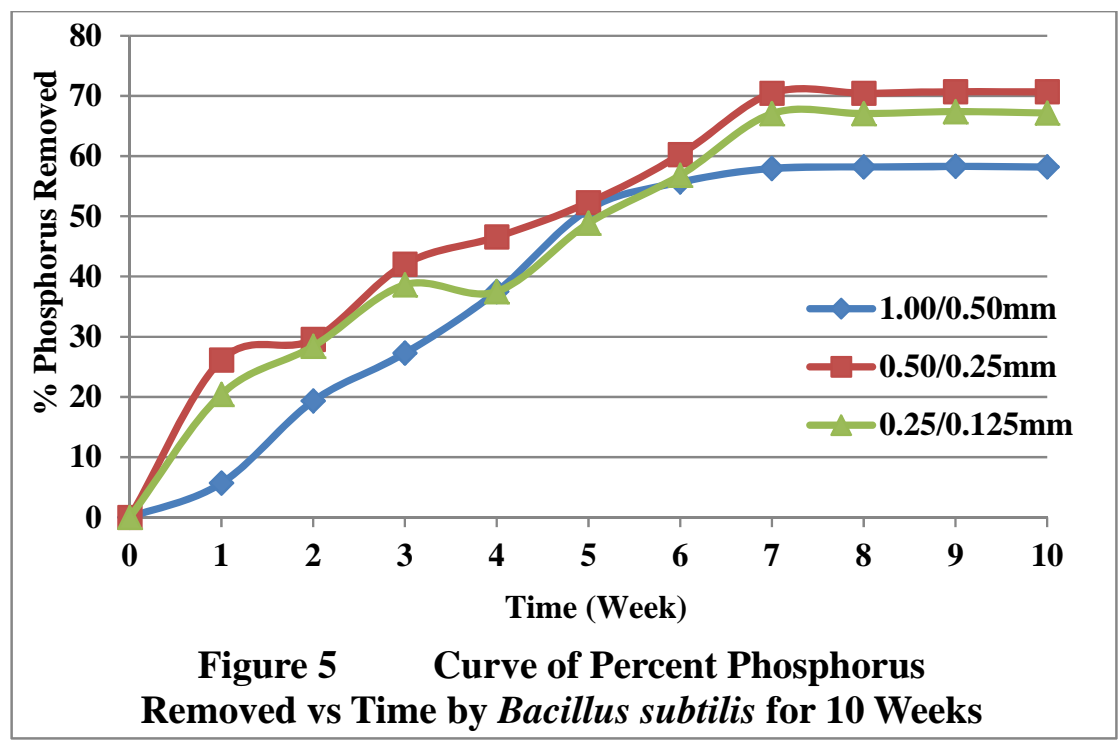




\section{CONCLUSION}

Bacillus subtilis has the capability to successfully remove phosphorus from Nigeria's Agbaja iron ore. The result of this research shows that an average of $65.73 \% \mathrm{P}$ removal across the 3 particle size fractions was achieved. The highest removal of $71.01 \% \mathrm{P}$ was achieved for $0.50 / 0.25 \mathrm{~mm}$.

\section{ACKNOWLEDGEMENT}

Particularly deserving great thanks are the staff and Heads of Departments of Microbiology and Chemical Engineering of University of Uyo, Akwa Ibom State. Few names will not fail to be mentioned and I wish to thank my Supervisor, Engr. (Dr.) C. N. Anyakwo who, actually not only conceived the work and provided the experimental strategies stage by stage, but also, brought his knowledge and expertise to bear on the entire work. Engr. Peter Asangausung, the Senior Technologist in-charge of the Chemical Engineering Laboratory where the bulk of this work was done, for his resourcefulness, keen interest and constant prayers; Dr. A. O. Ano of the Nigerian Root Crops Research Institute, Umuahia, Abia state, whose elastic patience limit was over stretched many times in an unprecedented manner by my over-keeping borrowed equipment worth millions of naira in order to complete this research.

\section{REFERENCES}

1. The Iron Ore Market. Downloaded on 5 December,2010 from www.unctad.org/infocomm/iron/covmar08.htm

2. Uwadiale, G. G. O. O. (1989). Upgrading Nigerian Iron Ores. Journal of Minerals and Metallurgical Processing. AIME, pp.117-123.

3. Uwadiale, G.G.O.O. and Hall, A.J. (1985). Mineralogy of Ironstone from Agbaja Deposit Nigeria in Relation to Beneficiation. Trans. Inst. Minerals \& Metallurgy. (Section B. Appl. Earth Science) 94(161-165).

4. Alafara, A. Baba., Adekola, F. A., Folashade, A. O. (2005). Quantitative Leaching of a Nigerian Ore in Hydrochloric Acid. J. Appl. Sci. Environ. Mgt.Vol 9(3) pp.15-20.

5. Astier, J. E., Donzeau, M., and Uwadiale, G. G. O. O. (1989). The Lokoja Oolitic Ironstone Deposit: Possible Use in the Ajaokuta Iron and Steel Plant. Journal of Mining and Geology Vol.25 Nos. (1\&2).

6. Adeleye, D. R. (1974). A Fauna from the Ironstone of the Middle Valley. Journal of Mining and Geology 8(pp.45-48).

7. Adeleye, D. R. (1973). Origin of Ironstones, an Example from the Middle Niger Valley. Journal of Sed. Petrology, 43(3). (pp.709-727).

8. Kudrin, V., Steel Making, MIR Publishers, Moscow, 1985, pp 82-83.

9. Uwadiale, G. G. O. O. and Nwoke, M. A. U.; Beneficiation of Agbaja Iron Ore by Reduction Roasting- Magnetic Separation: Semi Pilot Plant Scale-up and Establishment of Residence Point of Phosphorus, National Steel Council, Metallurgical Research and Tests Division, Jos, Nigeria, June 1983. 
10. Uwadiale, G.G.O.O. Beneficiation Studies of Agbaja Iron Ore, being text of a lecture delivered at a staff seminar, Department of chemistry, University of Benin, Nigeria, on May 1983.

11. Amadi, N. J., Odunaike, A. A and Marthur, G. P; Preliminary Bench Scale Beneficiation Studies with Three Lumps of Iron Ore Sample from Agbaja, Central Metallurgical Research and Development Institute, Jos, Nigeria, 1982.

12. Jain, N., Sharma, D. (2004). Biohydrometallurgy for Nonsulfidic Minerals - a Review. Geomicrobiology Journal, 21:3, p.135 - 144.

13. Delvasto, P. et al, 2005. Exploring the possibilities of biological beneficiation of ironores: The phosphorus problem. In: Proceedings of the 15th Steelmaking Conference, 5th Ironmaking Conference \& 1st Environment and Recycling Symposium IAS (CD-ROM). Argentinean Steelmaking Institute (IAS). San Nicolás, Buenos Aires, Argentina, pp. 71-82.

14. Dephosphorisation of an Iron Ore by a Filamentous Fungus, 2007. Pedro Delvasto, Antonio Ballester, Jesus Angel Munos, Maria Luisa Blasquez, Felisa Gonzalez and Camino Garcia-Balboa. Proceedings...VII Meeting of the southern Hemisphere on Mineral Technology, Brazil.

15. Pradhan, N. et al., 2006, ' Beneficiation of Iron Ore Slime using Aspergillus niger and Bacillus circulans', Bioresource Technology 97: 15, P. 1876-1879

16. Anyakwo, C. N., Obot, O. W., 2008, “Phosphorus Removal from Nigeria’s Agbaja Iron Ore by Aspergillus niger', International Research Journal in Engineering, Science \& Technology, Vol. 5 No. 1, pp 54-58.

17. Holt, John G., Krieg, Noel R., Sneath, Peter H. A., Stanley, James T., and Williams, Stanley T., 1994, “Bergy's Manual of Determinative Bacteriology," $9^{\text {th }}$ Edition, Lippincott Williams and Wilkins, Maryland, USA. pp. 559,562.

18. Jain S. K., (1982). An Introduction to Metallurgical Analysis: Chemical and Instrumental, India, New Delhi, Vikas Publishing House.

19. Bacterial Growth, Wikipedia - downloaded 5 January, 2011 from www.http://en.m.wikipedia.org/wiki/Bacterial_Growth 